The end point of this investigation was $S$ aureus on the wound wall; surgical-site infection as an end point would be preferable but would have required too large of a study population to accomplish the investigation in a single center.

In summary, bacterial air counts were reduced by the use of tightly woven reusable special scrub suits, as were the number of operations in which $S$ aureus were recovered from the air. By use of PFGE, it was possible to identify two cases of probable airborne transmission of $S$ aureus when wearing conventional scrub suits, whereas no such case was found when wearing special scrub suits. Neither skin carriage of $S$ aureus nor exposure to $S$ aureus in the air were risk factors for recovery of $S$ aureus on the wound wall at the end of the operation. When exposed to airborne $S$ aureus, the concomitant sternal carriage of $S$ aureus was a risk factor for having $S$ aureus on the wound wall. This shows the importance of careful preoperative disinfection of the patient's skin.

\section{REFERENCES}

1. Lidwell OM, Lowbury EJ, Whyte W, Blowers R, Stanley SJ, Lowe D. Effect of ultraclean air in operating rooms on deep sepsis in the joint after total hip or knee replacement: a randomised study. $\mathrm{Br} \mathrm{Med} \mathrm{J}$ (Clin Res $E d)$ 1982;285(6334):10-4.

2. Mangram AJ, Horan TC, Pearson ML, Silver LC, Jarvis WR the Hospital Infection Control Practice Advisory Committee. CDC Guideline for prevention of surgical site infection. Infect Control Hosp Epidemiol $1999 ; 4: 247-280$.

3. Wong ES. Surgical site infections. In: Mayhall CG, ed. Hospital Epidemiology and Infection Control. Baltimore, MD: Williams \& Wilkins; 1996:154-175.

4. Ståhle E, Tammelin A, Bergström R, Hambræus A, Nyström SO, Hansson HE. Sternal wound complications-incidence, microbiology and risk factors. Eur J Cardiothorac Surg 1997;11:1146-1153.

5. Loop FD, Lytle BW, Cosgrove DM, Mahfood S, McHenry MC, Goormastic M, et al. J. Maxwell Chamberlain memorial paper. Sternal wound complications after isolated coronary artery bypass grafting: early and late mortality, morbidity and cost of care. Ann Thorac Surg 1990;49:179-187.

6. Rodriguez-Hernandez MJ, de Alarcon A, Cisneros JM, MorenoMaqueda I, Marrero-Calvo S, Leal R, et al. Suppurative mediastinitis after open-heart surgery: a comparison between cases caused by gramnegative rods and by gram-positive cocci. Clinical Microbiology and Infection 1997;3:523-530.

7. Tammelin A, Domicel P, Hambræus A, Ståhle E. Dispersal of methicillinresistant Staphylococcus epidermidis by staff in an operating suite for thoracic and cardiovascular surgery: relation to skin carriage and clothing. J Hosp Infect 2000;44:119-126.

8. Allander C, Abel E. Investigation of a new ventilating system for clean rooms. Med Res Eng 1968;7:28-38.

9. Hambræus A, Hoborn J, Whyte W. Skin sampling-validation of a pad method and comparison with commonly used methods. J Hosp Infect 1990;16:19-27.

10. Benediktsdóttir E, Hambraeus A. Isolation of anaerobic and aerobic bacteria from clean surgical wounds: an experimental and clinical study. $J$ Hosp Infect 1983;4:141-148.

11. Miranda AG, Singh KV, Murray BE. DNA fingerprinting of Enterococcus faecium by pulsed-field gel electrophoresis may be a useful epidemiologic tool. J Clin Microbiol 1991;29:2752-2757.

12. Tenover FC, Arbeit RD, Goeing RV, Mickelsen PA, Murray BE, Persing DH, et al. Interpreting chromosomal DNA restriction patterns produced by pulsed-field gel electrophoresis: criteria for bacterial strain typing. $J$ Clin Microbiol 1995;33:2233-2239.

13. Lidwell OM. Air, antibiotics and sepsis in replacement joints. $J$ Hosp Infect 1988;11 (suppl C):18-40.

14. Blomgren G, Hambraeus A, Malmborg AS. The influence of the total body exhaust suit on air and wound contamination in elective hip-operations. J Hosp Infect 1983;4:257-268.

15. Rodriguez-Hernandez MJ, de Alarcon A, Cisneros JM, MorenoMaqueda I, Marrero-Calvo S, Leal R, et al. Suppurative mediastinitis after open-heart surgery: a comparison between cases caused by gramnegative rods and by gram-positive cocci. Clinical Microbiology and Infection 1997;3:523-530.

16. Whyte W, Hodgson R, Tinkler J. The importance of airborne bacterial contamination of wounds. J Hosp Infect 1982;3:123-135.

17. Whyte W, Hambraeus A, Laurell G, Hoborn J. The relative importance of routes and sources of wound contamination during general surgery, I: non-airborne. J Hosp Infect 1991;18:93-107.

18. Lidwell OM, Lowbury EJL, Whyte W, Blowers R, Stanley SJ, Lowe D. Bacteria isolated from deep joint sepsis after operation for total hip or knee replacement and the sources of the infection with Staphylococcus aureus. J Hosp Infect 1983;4:19-29.

19. Scheibel JH, Jensen I, Pedersen S. Bacterial contamination of air and surgical wounds during joint replacement operations. Comparison of two different types of staff clothing. J Hosp Infect 1991;19:167-174.

20. Ayliffe GAJ, Babb JR, Collins BJ. Dispersal and skin carriage of Staphylococci in healthy male and female subjects and patients with skin disease. In: Hers JFP, Winkler KC, eds. Airborne Transmission and Airborne Infection. Utrecht, The Netherlands: Oosthoek Publishing; 1973.

21. Hare R, Ridley M. Further studies on the transmission of Staph. aureus: $B M J$ 1958; Jan 11:69-73.

22. Hambraeus A, Laurell G, Nybacka $O$, Whyte W. Biliary tract surgery: a bacteriologic and epidemiologic study. Acta Chir Scand 1990;156:155162.

23. Hambraeus A. A microbiologist's view on perioperative hygiene and prophylactic antibiotic treatment. Acta Chir Scand 1987;538:96-100.

24. Noble WC, Valkenburg HA, Wolters CH. Carriage of Staphylococcus aureus in random samples of a normal population. $J$ Hyg (London) 1967;65:567-573.

25. Blowers R, Hill J, Howell A. Shedding of Staphylococcus aureus by human carriers. In: Hers I, Winkler KC, eds. Dispersal of Bacteria From the Human Body Surface. New York, NY: Halsted Press; 1972:432-434.

\title{
Intra-abdominal VRE Infections: The New Threat
}

\section{Gina Pugliese, RN, MS \\ Martin S. Favero, PhD}

Poduval and coinvestigators from Our Lady of Mercy Medical Center, Bronx, New York, conducted a study to determine the clinical course and outcome in patients with intra-abdominal vancomycin-resistant Enterococcus infections (VRE-A) and to identify probable risk factors for VRE-A. The incidence of VRE in the abdominal surgery setting is increasing. A comparative study was performed on patients with VRE-A and VRE infection in other sites (VRE-O) who were hospitalized for over 1 year. Of 89 nine patients with VRE, 6 had VRE-A, 24 had VRE-O, and 59 had VRE colonization. The VRE-A group was comprised of 1 patient with an inoperable Klatskin tumor and biliary sepsis, one AIDS and an infected pancreatic pseudocyst, 2 with fecal peritonitis, and 2 with biliary sepsis after surgery for common bile duct stones. All 6 patients with VRE-A had recent surgery before VRE isolation, as compared with 3 in the VRE-O group. Despite adequate treatment with intravenous chloramphenicol, resulting in eradication of VRE in all 6 VRE-A cases, the mortality rate remained high at $50 \%$.

The authors conclude that VRE should be recognized as an emerging nosocomial pathogen that causes potentially fatal intra-abdominal infections in the postsurgical setting. The impact of treatment on ultimate outcome needs further evaluation.

FROM: Poduval RD, Kamath RP, Corpuz M, Norkus EP, Pitchumoni CS Intraabdominal vancomycin-resistant $E n$ terococcus infections: the new threat.J Clin Gastroenterol 2001;32:333-335. 